\title{
MAP4K3 wt Allele
}

National Cancer Institute

\section{Source}

National Cancer Institute. MAP4K3 wt Allele. NCI Thesaurus. Code C116306.

Human MAP4K3 wild-type allele is located in the vicinity of 2 p22.1 and is approximately $188 \mathrm{~kb}$ in length. This allele, which encodes mitogen-activated protein kinase kinase kinase kinase 3 protein, is involved in the modulation of Jun signaling. 